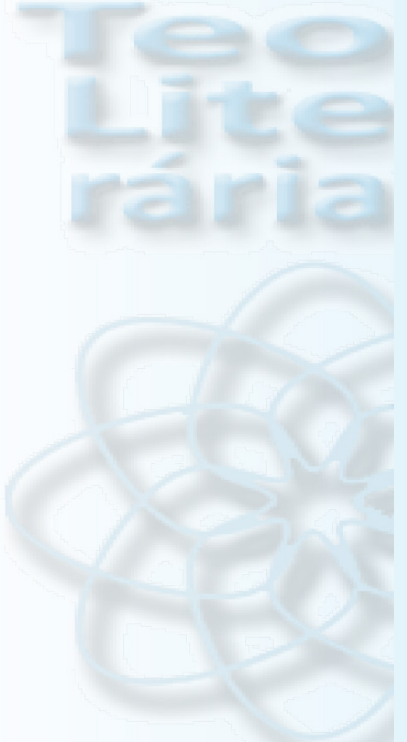

Arquivo enviado em

05/11/2018

e aprovado em

11/08/2019.

V. $9-$ N. $18-2019$

Pós-Doutorando em Teologia pela PUC-Rio, Pós-Doutor em Educação pela

Warsaw University (2018).

Doutor em Teologia pela FAJE (2017). É Fellow (Pesquisador) do International Institute for Hermeneutics (ALEMANHA).

\section{Por uma teopoética do perdão a partir de Paul Ricoeur}

For a theopoetic of forgiveness

from Paul Ricoeur

\section{René Armand Dentz}

\section{Resumo}

O nome de Deus adquire significado por meio de relações diferenciais nas quais sempre aparecem Deus/humano, Deus/mundo, Deus/deuses, infinito/finito, eterno/temporal, etc. Seja qual for o poder nominativo desse nome, e o status real de seu referente - o nome "infinito" é finito, o conceito "inconcebível" é concebível, e o nome "inefável" é bastante exprimível em palavras. Assim, é permitida a abertura à dimensão da promessa. A promessa, ela sim, inscreve-se na linguagem, à qual estamos sempre respondendo. Não se trata de um ato particular de fala, mas a promessa da própria linguagem. Não existe aqui salvação que salve ou prometa salvação. Mas o fato de que não exista necessariamente determinado conteúdo na promessa feita ao outro, e na linguagem do outro não torna menos indisputável a abertura da fala a algo que se pareça com messianismo, soteriologia ou escatologia. Trata-se de abertura estrutural, de messianismo, sem o qual o messianismo em si não seria possível. A linguagem dada a nós agita-se com diversos dons, e se inquieta com palavras de força donativa, como "dom". A indeterminação é justamente o que permite a promessa, que, por sua vez, possibilita o perdão. A inquietação descreve os gemidos da história e da linguagem para produzir 0 evento da vinda do totalmente outro, do futuro imprevisível. A história e a linguagem movimentam-se no ambiente da promessa, do 
espaço aberto entre o passado e o futuro.

Palavras-Chave: Nome de Deus. Dom. Promessa. Perdão.

\section{Abstract}

The name of God acquires meaning through differential relations in which God / human, God / world, God / gods, infinite / finite, eternal / temporal, etc. always appear. Whatever the nominative power of that name, and the actual status of its referent - the name "infinite" is finite, the concept "inconceivable" is conceivable, and the name "ineffable" is quite expressible in words. Thus, openness to the promise dimension is allowed. The promise, yes, is inscribed in the language, to which we are always responding. It is not a particular act of speech, but the promise of language itself. There is no salvation here that saves or promises salvation. But the fact that there is not necessarily certain content in the promise made to the other, and in the language of the other, does not make the opening of speech to anything resembling messianism, soteriology, or eschatology less indisputable. It is a structural opening, of messianism, without which Messianism itself would not be possible. The language given to us is agitated with various gifts, and is troubled with words of giving force, as "gift." Indeterminacy is precisely what allows the promise, which, in turn, enables forgiveness. Uneasiness describes the moans of history and language to produce the event of the coming of the totally other, unpredictable future. History and language move in the environment of promise, the open space between the past and the future.

Keywords: Name of God. Gift. Promise. Pardon.

\section{Introdução}

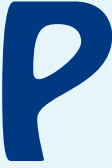

odemos afirmar a existência de uma "filosofia da linguagem" que perpassa a obra de Ricoeur e que pretende elucidar, como obra racional, as múltiplas funções do significar humano. Essa proposta não se busca, contudo, como filosofia da consciência. No intuito de superar o conflito, Ricoeur irá elaborar uma dialética da arqué e do télos, propondo uma compreensão hermenêutico-dialética ultrapassadora do conflito. Com isso, a hermenêutica psicanalítica é vista não como reducionismo desmitificador, 
mas como reveladora de uma arqué dos símbolos, e das ciências da religião, como télos. Atinge-se, dessa forma, sua complementaridade com a criação de um novo nível de experiência. Essa mediação é interpretada por Ricoeur em dois momentos. Primeiro na Simbólica do Mal, onde a hermenêutica é reduzida à interpretação dos símbolos enquanto estes são vistos como expressões de duplo sentido. E depois no Conflito das Interpretações, como abertura do sentido, expondo-se ali o caráter polêmico da hermenêutica dividida entre a operação de desmistificação do "simbolismo" e o ato de sintetizar um sentido mais rico, elevado, espiritual. Naquele momento, a polêmica se fazia representar no conflito principal que o filósofo francês considerava ser entre a psicanálise e as ciências da religião. O horizonte do sagrado, que já em $\mathrm{O}$ Voluntário e o Involuntário era considerado "a origem radical da subjetividade", encerra o Ensaio sobre Freud, assim como a segunda revolução copernicana encerrava a travessia da Simbólica do mal. A semeIhança desse discurso com as obras anteriores é indiscutível, mas não menos o são as novidades. Há uma espécie de "hermeneutização" da fenomenologia, uma tematização e priorização progressiva do ser sobre o pensar. O sujeito não é mais o portador da significação. É mais levado por ela, pela dimensão onto-semântica dos símbolos religiosos, da linguagem do desejo e das produções culturais. A consciência deixar de ser centro e o sujeito encontra-se pluralmente descentrado: para baixo (o involuntário corporal), para trás (o inconsciente psicanalítico), para frente (o espírito) e para cima (transcendência). Só pode reapropriar-se de si mesmo, não pelo caminho curto da intuição ou visão especular de si mesmo, mas pelo caminho longo da decifração do seu "outro", quer seja o instintual, o desejo inconsciente, o desejo de reconhecimento na trama das relações intersubjetivas do mundo da cultura, ou o 
Totalmente-Outro do Sagrado. Arké, Télos e Escaton são os novos centros dinâmicos que estruturam e determinam nossa subjetividade ancorada sempre em um passado que tenta nos condicionar, mas que se encontra aberta em uma "poética da vontade", para o possível, a esperança e a graça.

\section{Caminhos do Dom e do Perdão}

Uma indiferença fundacional instaura o sujeito em sua relação com o mundo, de forma que tal indeterminação indica a abertura da existência em sua gênese fenomenológica. A gênese da subjetividade pronominal virá em seguida para tentar ultrapassar essa indeterminação, com a finalidade de ensinar-nos a viver no mundo da vida. Mesmo assim, o nada permanece como a origem sem origem do devir, aquém de toda determinação de significação, de valor, de sentido e até de fundamento1.

A postura mais autêntica torna-se uma existência niilista, enquanto é vivida nos limites de si mesmo. Uma existência vivida como tal por um sujeito vulnerável porque se confrontou por experiência própria com uma vida que não cessa de olhar de frente para a morte. O niilismo vivido ao extremo, enquanto possibilidade de um mundo outro, não o da Mesmidade, mas o da Diferença

1. Jean-Luc Nancy propõe uma desconstrução do cristianismo segundo sua lógica da kénosis do Logos, com o conseguinte despojo da potência divina e do papel do cristianismo neste momento particular do ocidente. Cristo teria inaugurado assim a aguda consciência da agonia enquanto presença-ausência sempre atuante na meta-história. Tudo sucede como se o cristianismo tivesse desenvolvido com nenhum outro o fez uma afirmação de poder, dominação e exploração teológico-econômico-política, da qual Roma seria o pesado símbolo e ao mesmo tempo uma parte da realidade, bem como uma afirmação inversa de despojo e abandono de si, cujo ponto de fuga seria o auto-desvanecimento. A questão deve ser então, naturalmente, a da natureza da estrutura desse auto-desvanecimento: ultrapassamento dialético, absolutamente novo... De uma maneira ou de outra, não se trata não senão disto: como o monoteísmo se engendra como humanismo, e como o humanismo enfrenta a finitude que entrou assim na história. (NANCY, 2005, p.60) 
conduzida como vida até o final. Mundos aquém do fundamento, da significação, do sentido e do valor, convertidos em verdadeiros ídolos nos sistemas de totalidade. Um mundo, em última instância, de frente para o nada. Viver até o limite da consciência da própria vulnerabilidade, da ambigüidade da história e da polissemia da linguagem e das ações humanas. Ou seja, trata-se da condição vulnerável extrema própria do sujeito em relação que superou a lógica da totalidade, aquilo que Ricoeur denomina "ExpressõesLimite" e que chama de "existência para a morte". Assim temos a dimensão da esperança! No instante mesmo da morte, como um rasgamento do véu que dissimula a fuga fundamental sob a forma de revelações históricas. Projeto assim não um após-a-morte, mas um morrer que seria a última afirmação da vida. Minha experiência própria de um fim da vida se nutre desse anseio mais profundo de fazer do ato de morrer um ato de vida. Esse voto, eu o estendo à mortalidade mesma, como um morrer que permanece interno à vida. Dessa maneira, a própria mortalidade deve ser pensada sub specie vitae e não sub specie mortis. Isso explica que eu já não ame nem utilize o vocabulário heideggeriano do ser para a morte. Diria eu em lugar disso: ser até a morte. O que importa é ser um vivente até a morte, levando o desapego até o extremo do luto da preocupação com a vida posterior. Aqui vejo que se fundiram o vocabulário do mestre Eckhart e o de Freud: "desapego" e "trabalho de luto". (RICOEUR, 1995, p. 236)

\section{A Liberdade segundo a Esperança e a Teologia do Nome Divino}

A "possibilidade de ser" é escatológica. A ontologia é dinâmica. Essas afirmações implicam na vivência da esperança e da esca- 
tologia no âmbito da possibilidade de ser. No caso da ontologia do nome divino, para Ricoeur engloba-se tanto o ser de Aristóteles com o ser do Êxodo 3, 14. É neste alargamento que Kearney (2006) sugere haver uma passagem do homem capaz para o Deus capaz. A escatologia torna-se, portanto, o "segredo" intelectual e espiritual. A passagem do ser ao além do ser acontece discretamente em um espaço onde surge um horizonte escatológico no qual Ricoeur pode, a partir dele, articular teologia e filosofia.

Desse modo, é de fundamental importância notar que a escatologia em Ricoeur é, segundo Kearney (2006), a escatologia do Deus capaz que vai ao encontro litúrgico do homem capaz. Este encontro dá-se desde um entrelaçamento confessional, como nas narrativas ritualísticas, até o quiasma erótico no livro bíblico Cântico dos Cânticos. Portanto, o centro da escatologia ricoeuriana está no selamento da aliança no ser humano tanto como sabedoria e desejo. É no vai-e-vem nupcial que o Eu posso do homem capaz encontra seu eco no Tu podes do Deus capaz - capaz de ser nomeado - e, vice-versa, diante de uma alteridade do Eu-Tu. É, dessa forma, um movimento duplo de sensibilidade e espiritualidade, de imanência e transcendência, de finitude e infinitude, que comporta a função metafórica do nome divino. Portanto, diante da dinâmica do nome divino e da própria vivência, em seu primeiro livro póstumo, Ricoeur concluiu que a mediação de sua religiosidade pelo nome divino é um acaso transformado em destino por uma escolha contínua. Este acaso o fez cristão. Para o filósofo francês, cristão seria aquele que professa a adesão primordial à vida, palavras e morte de Jesus. Adesão entendida como a palavra grega Pistis. Ele adere à profundidade e ao mistério de Javé, nome que determina uma tradição e interpelação na vida, fazendo-o ela- 
borar uma filosofia que vai da atestação à possibilidade, de modo que o acaso não é mero acaso, pois é assumido como escolha e transformado em continuidade pela esperança. É neste âmbito que acontece uma teologia do nome divino, sobretudo narrativa, que transmite um modo de ser, uma coragem de ser. Dessa forma, ao teorizar sobre a teologia do nome divino, Ricoeur dá espaço à teologia narrativa ao invés de uma teologia dogmática ou ainda uma onto-teologia sobre Deus².

Quando se suspendem as modalidades passionais do querer, isso faz aparecer o querer e a existência humana como aquilo que dá sentido. Ricoeur estabelece que, para separar o "mundo subjetivo da motivação" do "universo objetivo da causalidade", para resgatar essa necessidade que "eu sinto" pelo fato de que somos vivos, torna-se necessário organizar a ideia tríplice de motivação, espontaneidade, necessidade vivida em torno de um eu quero constituinte (transcendental). Portanto, é necessário "manter em suspenso a escravidão que oprime o querer, para penetrar até essa possibilidade fundamental do eu que é sua responsabilidade" (RICOEUR, 2007, p. 85). A omissão da culpa é necessária para compreender a reciprocidade do voluntário e do involuntário, reciprocidade essa que os torna inteligíveis um pelo outro em sua unidade. A liberdade é constituinte de todo o involuntário, inclusive da necessidade, não sendo suprimida pela culpabilidade. "A dialética do voluntário e do involuntário é a estrutura indiferenciada da

2. O nome divino porta metáforas que configura tradições plurais. O auge desta interpretação está na poética que promove a compreensão do mundo diante do texto. A prática de vivência da fé do nome divino é transferida do texto para a vida. A essência poética possibilita refazer o mundo segundo a visada essencial da relação do sujeito com a narrativa bíblica. A palavra Deus torna-se uma expressão-limite que leva à experiência-limite, como, por exemplo, a superação da ética e do político para a mudança do mundo que é inaugurado pelo texto. O mundo que habitamos é refletido no mundo do texto, e o mundo do texto é a chave de acesso para o mundo habitado. 
inocência e da culpabilidade [...] O homem não é metade homem e metade culpado; ele é sempre poder de decidir, de mover e de consentir [...]" (RICOEUR, 2007, p. 85).

A vontade humana e, portanto, a liberdade, é assim vista como uma construção ambígua. Em qualquer momento em que um sujeito manifeste sua vontade, esta está impregnada pelo outro, o qual se faz anterior à formação da vontade. Portanto, somos em nossa própria constituição, heterônomos. No entanto, por meio da História da Salvação, descobrimos Deus se doando, gratuitamen$t^{3}$. Trata-se não de um processo histórico mimético, pois ela seria, em si mesma, um produto da memória cuja formação já está distorcida. Trata-se, portanto, de uma contra-história! Ou seja, de dentro para fora, como libertação da constituição distorcida de tempo dos homens ${ }^{4}$.

\section{A Dimensão da Promessa e da Graça}

Deus é amor, em vez de ser, e revela a divindade como amor aos que amam. O amor funciona, segundo Marion, como princípio hermenêutico e permite que novos fenômenos possam ser vistos.

3. A ressurreição é o evento que permite uma história humana totalmente nova e, até o momento, não imaginada. Ou seja, é possível agora fazer uma releitura de toda história humana a partir de outra perspectiva, que havia sido até o momento impedida pela realidade da morte. Trata-se de uma possibilidade de passagem da história à historicidade, sendo agora inaugurado um novo horizonte, aquele que inclui o perdão.

4. Nas palavras de MENDOZA (2011, p.30):

$\mathrm{Na}$ experiência do perdão, com efeito, instaura-se um mútuo reconhecimento que nada tem que ver com a rivalidade, na qual todos nós nos encontramos presos, até às vezes o outro, que é tão frágil e vulnerável como nós mesmos. Talvez seja essa experiência fundacional do desconhecimento-reconhecimento de si com relação ao outro o que é apenas insinuado no relato de Abel e sua história com seu irmão Caim. Uma pergunta dirigida tanto a Deus como a nós, os seres humanos: "Onde está teu irmão?". Talvez também esse processo existencial, que radica na passagem do desconhecimento ao reconhecimento do outro, seja aquilo vivido por dois discípulos de Jesus de Nazaré, Maria Madalena e Pedro, os primeiros, quando se encontraram com seu rabi no resplendor da manhã de Páscoa. 
Trata-se de conhecimento que se alcança por meio do encontro fundamentado no movimento da vontade. O conhecimento de Deus na forma de amor realiza-se quando Deus capacita o amante a amar. Ou seja, Deus não é mais conhecido como objeto, mas no crescente excesso de doação, como Dom. Este conhecimento é, portanto, dependente da preparação do amante para designar a "experiência" de excesso com o nome de "Deus". O dom nos capacita a ir além do ser da metafísica: ele desafia até mesmo a diferença ontológica tornando-a inútil ou sem sentido. O nome de Deus, que é teológico por excelência é algo a ser apagado em nome da imensa transcendência de qualquer conceito a seu respeito. Buscar um pensamento incondicionado por algum sujeito e sem limites de horizonte é um sonho que se finaliza no momento em que surge a linguagem. $O$ nome de Deus deveria ser um traço que se apaga por si mesmo. Assim, a teologia negativa percebe que o caminho para a divindade além de Deus, ao Deus além do traço, é o desvio do ato fático. Afinal, Deus só pode ser atestado como inconcebível ${ }^{5}$.

A linguagem dada a nós agita-se com diversos dons, e se inquieta com palavras de força donativa, como "dom". A indeterminação é justamente o que permite a promessa, que, por sua vez, possibilita o perdão. A inquietação descreve os gemidos da história e da linguagem para produzir o evento da vinda do totalmente outro, do futuro imprevisível. A história e a linguagem movimentam-se no ambiente da promessa, do espaço aberto entre o passado e o futuro.

5. Somente o ser infinito pode reduzir a diferença na presença. Nesse sentido, o nome de Deus, pelo menos como é pronunciado no racionalismo clássico, é o nome da indiferença. Não devemos, portanto, falar de "preconceito teológico", funcionando esporadicamente quando se trata da plenitude do logos; o logos como sublimação do traço é teológico (DERRIDA, 1967). 
Ricoeur propõe um saber narrativo que fundamente as mudanças da intriga e do enredo e dos diferentes gêneros literários ou variações imaginativas apresentadas em uma Poética. A condição necessária é fornecer suporte à reconfiguração da mímesis, do muthos e da karthasis, os conceitos mais fundamentais da poética. Nesse momento podemos também articular a poética à hermenêutica do si, que tem na figura da identidade narrativa sua mais importante característica. Esse caminho evidencia seu projeto hermenêutico e sua poética da vontade, que, mesmo inacabada, pode ser entendida a partir de sua teoria do agir, sobretudo em Soi-même comme un autre e em Parcours de la reconaissance.

\section{Caminho da alteridade}

A discussão acerca da alteridade resulta de um modo muito singular que Ricoeur abordou a subjetividade. Em seu último ciclo filosófico, tomando como ponto de partida a afirmação de um "cogito ferido", Ricoeur elabora uma hermenêutica do si como sequência tardia de sua proposta inicial de filosofia reflexiva. No entanto, podemos destacar que agora ele retoma esse projeto a partir de uma filosofia reflexiva com "vocação ontológica". Seu principal intento é demonstrar de que modo a alteridade se vincula ao sentido e à constituição ontológica da ipseidade.

[...] O problema filosófico central da filosofia reflexiva será o da "compreensão de si", enquanto sujeito das operações de conhecimento, vontade, estima, responsabilidade. Assim, não é difícil perceber até que ponto esta filosofia reflexiva dos anos de formação ricoeuriana volta a estar presente, atravessada pela hermenêutica, na última etapa da sua obra, e refiro-me fundamentalmente à hermenêutica do si-mesmo que encontramos desenvolvida em Soi-même comme un autre (VILLAVERDE, 2004, p. 76). 
Ricoeur enfatiza que a alteridade que está no centro da ipseidade é atestada apenas em experiências fundantes de passividade que se alteram devido ao foco estar colocado na relação entre o si e o si-mesmo, de tal maneira que pode-se afirmar um tripé de passividade formado pela experiência do corpo próprio, pela relação de intersubjetividade e pela problemática da consciência. "Se não cria a alteridade, sempre pressuposta, confere-lhe uma significação específica: a admissão de que o outro não está condenado a continuar estranho, mas pode tornar-se meu semelhante, a saber, alguém que, como eu, diz 'eu’” (RICOEUR, 1990, p. 386).

[...] O outro não é apenas uma contrapartida do Mesmo, mas pertence à constituição íntima de seu sentido, com efeito, as várias maneiras como o outro do si afeta a compreensão de si por si marcam precisamente a diferença entre o ego que se põe e o si que só se reconhece através desse afetar-se (RICOEUR, 1990, p. 380).

Dessa maneira, o movimento do ego ao alter ego apenas alcança sua máxima produtividade quando coordenado com o movimento que vem de outrem em minha direção. Por outro lado, para que se concretize tal dialética, faz-se necessário ultrapassar a radicalidade de um pensamento da alteridade absoluta que enfatiza a dissimetria entre o Mesmo e o Outro. Por isso, para que se efetive uma síntese entre o movimento ético do outro em direção ao si e o movimento gnosiológico do si em direção ao outro, é preciso imaginar relacionado ao si uma capacidade de recepção que resulta de uma estrutura reflexiva e uma habilidade de discernimento que possibilita o reconhecimento e a interiorização da voz do outro como convicção e uma consequente reciprocidade. É por esse caminho que a alteridade se abre ao reconhecimento. 


\section{Caminho do reconhecimento}

A partir das categorias antropológicas da identidade, alteridade e reconhecimento desde as obras Soi-même comme un autre e Parcours de la reconnaissance, podemos buscar entender o conceito de capacidade e o que permite a identificação e o reconhecimento do homem em Ricoeur como "homem capaz", como já trabalhamos no segundo capítulo, mas que agora retomamos na perspectiva do dom e do ágape. Dessa forma, podemos explicitar os pressupostos ontológicos da realização ética do homem capaz.

Ricoeur se apropria do conceito de Jean Nabert de afirmação originária para conceder à conclusão final de L'homme faillible, além de um fundamento reflexivo, um conceito central que permita uma unificação das diversas funções do sujeito. "Consciência moral e conhecimento intelectual são, em última instância, animados por uma afirmação originária que preside a operação de consciência dos sujeitos que pensam e que querem fundando sua reciprocidade em sua unidade originária" (RICOEUR, 1990, p. 184). Por isso, na dimensão da fenomenologia e da hermenêutica do homem capaz, a noção de atestação relaciona-se primariamente à crítica que nosso filósofo propõe à imediatidade do cogito e à certeza que o mesmo reinvidica.

Uma vez que a realização ética expõe a possibilidade de existência mais concreta do si, na condição de conatus, enquanto esforço de ser e desejo de existir, podendo ser concebido como o fundamento ontológico a partir do qual se pode afirmar eticamente o ser humano. No entanto, o si é atestado como capaz de uma ação passível de uma qualificação ética somente se ele for capaz de efetivar uma retomada pessoal da potência originária de agir. Essa condição relaciona a reflexão de Ricoeur sobre a atestação 
às propostas acerca da imputação e do reconhecimento de si.

Minha tese nesse plano é a de que existe um parentesto semântico estreito entre a atestação e o reconhecimento de si, na linha do "reconhecimento da responsabilidade" atribuído aos agentes da ação pelos gregos de Homero e Sófocles a Aristóteles: ao reconhecer ter cometido um determinado ato, os agentes atestavam implicitamente que eram capazes de cometê-lo (RICOEUR, 2006, p. 107).

O primeiro modelo de reconhecimento inclui relações que implicam vínculos afetivos fortes com poucas pessoas. Concretizado nas figuras empíricas do amor a partir da aprovação mútua este nível pré-jurídico de reconhecimento tem como forma de negação a humilhação proveniente da recusa da aprovação. Em um nível intermediário, está situado o reconhecimento no plano jurídico. Este implica admitir a validade de uma norma e identificar cada pessoa como livre e igual a todas as outras. Essa estrutura dual do reconhecimento jurídico marcada pela conjunção entre validade universal da norma e a singularidade das pessoas implica a "conexão entre a ampliação da esfera dos direitos reconhecidos às pessoas e o enriquecimento das capacidades que esses sujeitos reconhecem em si mesmos" (RICOEUR, 2006, p. 212). Resultado de lutas históricas pelo reconhecimento, a ampliação da esfera normativa dos direitos se concretiza tanto pela enumeração dos direitos subjetivos, quanto pela atribuição desses direitos a novos grupos. Nesse segundo aspecto, Ricoeur sustenta que, ao assumir a forma específica de sentimentos de exclusão e alienação, a experiência do menosprezo provoca uma indignação que pode fornecer às lutas sociais a dimensão de uma guerra.

O reconhecimento como identificação de alguma coisa ou de alguém, como reconhecimento de si como sujeito e autor dos atos 
de uma vida, e como reconhecimento mútuo sob a forma de gratuidade dividida. Ou seja, podemos concluir que no desenvolvimento da humanidade, sempre foi crucial a busca do ser pela conquista de reconhecimento. Dentro dessa perspectiva, podemos afirmar que em sua busca, o reconhecimento pressupõe a busca do outro, não somente pela subjetividade, mas pela intersubjetividade. Jervolino (1996) se indaga se caberia aqui a questão se a alternativa edificante oferecida no processo de reconhecimento pode ser inaugurada na subjetividade. Por meio da fenomenologia hermenêutica, Ricoeur confere ao eu a possibilidade de passar de um simples espectador do mundo e dos outros a um sujeito encarnado, que reconhece a si e ao outro através da história e pelas narrativas.

Sob a denominação de estados de paz, compreendidos entre eles os gestos de grandeza e de perdão ou a prática da discriminação invertida, o autor indicará os diferentes caminhos do reconhecimento positivo. Mas, no contexto geral de sua ética, há um elemento tomado da moral kantiana que vai desempenhar um papel complementar em relação à solicitude e será a peça chave na proposição de uma nova forma de reconhecimento: a noção de respeito (RICOEUR, 2008, p. 8).

Nessa condição, é notável a despreocupação dos polos do dar e retribuir, uma vez que estes não se tornam obrigatórios, não se limitam ao exterior do outro, pois estão além, alcançando a dimensão da gratuidade, no sentido estrito do termo ágape. Eis mais um fundamento para o perdão. Ora, na dimensão de uma antropologia filosófica que tem como ponto de partida a desproporção e a falibilidade (conforme abordamos no capítulo anterior), Ricoeur aborda os planos da linguagem, da ação, da narratividade e da responsabilidade. Dessa maneira, a noção de capacidade cujo aspecto central consiste no "poder fazer", mostra o fundamento do sujeito 
que se tornará "sujeito de direito".

Dessa forma, podemos afirmar que a especificidade da noção de reconhecimento de si vincula-se ao fato de nos remeter a uma experiência mais originária que nos precede e que nos leva a compreender a atestação como uma retomada reflexiva de uma compreensão mais originária do "eu posso".

Ao procurar nos estados de paz uma alternativa à luta no processo de reconhecimento, Ricoeur busca reinvindicar os direitos de uma "hermenêutica da mutualidade" perante a lógica da reciprocidade. Por isso, esse contraste entre reciprocidade e mutualidade se coloca como o pressuposto fundamental da afirmação de um reconhecimento mútuo simbólico, representada pela troca de dons cerimonial, como alternativa ao paradigma da luta no processo de reconhecimento (RICOEUR, 2006, p. 246). Nesse momento, ao se aproximar do debate acerca dos paradoxos do dom e do contradom.

\section{Amor e Justiça: a Regra de Ouro}

Tomando como ponto de partida a existência de uma desproporção entre amor e justiça, Ricoeur busca dar ênfase às formas de discurso, ou seja, a poética do amor e a prosa da justiça. No âmbito deste último, afirma que "a justiça argumenta, e de forma muito particular, confrontando razões pró ou contra, supostamente plausíveis, comunicáveis, dignas de serem discutidas pela outra parte" (RICOEUR, 2007, p. 17). No entanto, esse conflito no nível da argumentação inerente ao discurso jurídico encerra-se em uma decisão fundamentada em uma racionalidade específica. Dessa forma, para Ricoeur, "o estágio mais alto que o ideal de justiça pode pretender é o de uma sociedade em que o sentimento de 
dependência mútua permanece subordinado ao de desinteresse mútuo" (RICOEUR, 2007, p. 21).

Ao final desse caminho de ênfase na desproporção entre o amor e a justiça, Ricoeur destaca que as duas sugerem pretensões acerca da prática individual e social, que "é a ação que amor e justiça se dirigem, cada um a seu modo, é a ação que ambos reinvindicam" (RICOEUR, 2007, p. 22). Assim, ele pretende superar a dicotomia entre os dois termos, propondo uma interface entre a poética do amor e a prosa da justiça.

Dessa maneira, a medida do dom é o amor aos inimigos, mesmo que seja algo quase impossível, reafirma a Regra de Ouro.

A vós que me escutais, eu digo: Amai os vossos inimigos e fazei o bem aos que vos odeiam, bendizei os que vos amaldiçoam, e rezai por aqueles que vos caluniam. Se alguém te der uma bofetada numa face, oferece também a outra. Se alguém te tomar o manto, deixa-o levar também a túnica. Dá a quem te pedir e, se alguém tirar o que é teu, não peçais que o devolva. O que vós desejais que os outros vos façam fazei-o também vós a eles. Se a mais somente aqueles que vos amam, que recompensa tereis? Até os pecadores amam aqueles que os amam. $E$ se fazeis o bem somente aos que vos fazem bem, que recompensa tereis? Até os pecadores fazem assim. E se emprestais somente àqueles de quem esperais receber, que recompensa tereis? Até os pecadores emprestam aos pecadores, para receber de volta a mesma quantia. Ao contrário, amai os vossos inimigos, fazei o bem e emprestai sem esperar coisa alguma em troca. Então, a vossa recompensa será grande, e sereis filhos do Altíssimo, porque Deus é bondoso também para com os ingratos e os maus. Sêde misericordiosos, como também o vosso Pai é misericordioso. Não julgueis e não sereis julgados; não condeneis e não sereis condenados; perdoai e sereis perdoados. Dai e vos será dado. Uma boa medida, calcada, sacudida, transbordante será colocada no vosso colo; porque com a mesma medida com que medirdes os outros, vós também sereis medidos (LC, 6, 32-37). 
Aqui se apresentam o Mandamento do amor aos inimigos e a Regra de Ouro, que podem ser entendidos, nesse contexto, como paradigma da dialética entre amor e justiça.

[...] O mandamento de amor não abole a Regra de Ouro, mas a reinterpreta no sentido da generosidade e, assim, faz dela um canal não apenas possível, mas necessário de um mandamento que, em razão de seu estatuto supraético, só alcança a esfera ética à custa de comportamentos paradoxais e extremos (RICOEUR, 2012, p. 29).

\section{Amor e Justiça: além da Regra de Ouro, existe a Superabundância}

É a partir dessa nova perspectiva que o perdão existe, na perspectiva da lógica da superabundância. O perdão não pertence totalmente ao domínio moral da reciprocidade e do reconhecimento implicados nos modelos das trocas de memórias. Ele é de outra ordem, daquela da economia do dom e da superabundância, daquilo que podemos intitular de "poética da vontade". Por poética, é preciso entender um duplo sentido de criatividade no plano da dinâmica do agir e do hino no plano da expressão verbal. Sua potência poética consiste em frisar a lei da irreversibilidade do tempo, considerando a carga da culpabilidade que paralisa a relação entre os homens que agem e sofrem sua própria história. Jesus muda a lógica da equivalência, como no exemplo citado por Ricoeur, o ensinamento do mestre se concretiza pela exceção à regra e não por meio da regra.

Vocês ouviram o que foi dito: "Olho por olho e dente por dente". Eu porém, Ihes digo: não se vinguem de quem fez o mal a vocês. Pelo contrário: se alguém Ihe dá um tapa na face direita, ofereça também a esquerda! Se alguém faz um processo para tomar de você a túnica, 
deixe também o manto! Se alguém obriga você a andar um quilômetro, caminhe dois quilômetros com ele! Dê a quem lhe pedir, e não vire as costas a quem pede emprestado (Mt 5, 38-39b-42).

Ricoeur sugere que ordens absurdas foram pronunciadas pela intenção de alterar nossa tendência natural. Para isso, é criada uma tensão deliberada entre a ordem e a maneira que nós vivemos, pensamos e agimos normalmente. Nessas situações é inútil esperar a clareza da lei, pois o ensinamento a ultrapassa. A direção que as palavras de Jesus sugerem se destina à imaginação ética, não à nossa vontade de obedecer sem resistência à regra. Ou seja, a capacidade imaginativa se mostra como o poder de nos abrir a novas possibilidades, de descobrir outra via, vendo as coisas de outro modo, alcançando uma nova regra recebendo o ensinamento de exceção. Aqui se situa o perdão, pois ele também é um bom exemplo de evento excepcional e é uma possibilidade desta mesma imaginação ética.

É importante destacar que a regra de ouro é enunciada no meio do Sermão da Planície e não somente antes do mandamento do amor aos inimigos. Ela está no centro de uma série de exigências de atitudes e ações extremas, que se fundamentam na lógica do dom e, por isso, não pressupõem a reciprocidade. Paul Ricoeur sublinha que a citação de Lucas da regra de ouro é, em verdade, um desafio para se ir além da regra de ouro em seu sentido literal. Para o filósofo, a regra de ouro é integrada plenamente na narrativa evangélica à nova ética, à nova lógica de Jesus, que seria inconcebível sem uma nova economia das relações humanas, a economia do dom (SALLES, 2013, p. 115).

A regra de ouro evidencia que o sujeito capaz de agir é potencialmente um transgressor, capaz de tratar o outro como um meio: "Para dramatizar essa inicial dissimetria, direi que o outro é potencialmente a vítima de minha ação tanto quanto seu adversário" 
(RICOEUR, 1995, p. 294). Por isso, o problema moral da regra de ouro é compreendido de tal modo que não poderia ser solucionado pelo princípio da autonomia.

Nisso reside a principal diferença entre Kant e a regra de ouro: ao pôr a violência no mesmo lugar que Kant pôs o desejo, a regra de ouro incorpora um aspecto fundamental da ação humana, o poder exercido em e sobre outro, e, assim, recusa delimitar uma linha entre o a priori e o empírico (RICOEUR, 1995, p. 296).

Aqui podemos lembrar uma forma muito defendida por nosso filósofo quando trata das Escrituras: o provérbio. Submetido ao paradoxo, não orienta senão desorientando. Através de uma ausência de lógica, surge uma nova lógica. Quem buscar conservar sua vida, perdê-la-á, e quem a perder, salvá-la-á (Mc 8, 35; Lc 17, 33).

O paradoxo consiste em duas afirmações opostas. De um lado, retoma o pressuposto sobre o qual o uso das palavras de sabedoria se apóia, a saber, o projeto de fazer da existência um todo contínuo. Porque quem pode forjar um projeto coerente perdendo sua vida para salvá-la? De outro lado, afirma que apesar de tudo, a vida é concedida através desse caminho paradoxal. Se assim não fosse, teríamos uma simples negação, seja cética, seja irônica, por exemplo, do projeto da existência (RICOEUR, 2006, p. 196).

O mito do dilúvio também é mencionado por Ricoeur como um enfrentamento da lógica da equivalência. Aqui podemos conceber uma lógica diferente apresentada, transformando em parábola a ressurreição das águas da humanidade ( $G n$ 8, 21-22). Por isso, é sugerida outra lógica, aquela da superabundância, conforme já afirmamos em momentos anteriores.

Javé viu que a maldade do homem crescia na terra e que todo projeto do coração humano era sempre mau. Então Javé se arrependeu de ter feito o homem sobre a terra, e seu coração ficou magoado. E Javé disse: "Vou 
exterminar da face da terra os homens que criei, e junto também os animais, os répteis e as aves do céu, porque me arrependo de os ter feito (Gn 6, 5-7).

Javé aspirou o perfume, e disse consigo: "Nunca mais amaldiçoarei a terra por causa do homem, porque os projetos do coração do homem são maus desde a sua juventude. Nunca mais destruirei todos os seres vivos, como fiz. Enquanto durar a terra, jamais faltarão semeadura e colheita, frio e calor, verão e inverno, dia e noite" (Gn 8-21).

Verificamos uma lógica semelhante é a que se fundamenta o apóstolo Paulo, sobretudo na Epístola aos Romanos, onde afirma a lógica da superabundância, do excesso e da graça. Paulo enfatiza tal perspectiva utilizando a expressão "com mais forte razão", como se a abundância de expressão da exortação devesse acompanhar aquela do dom que ele concretiza.

A coisa nova em Paulo é o que ele tornará, por contraste infinitamente precioso, ou seja, o que é novo - Jesus Cristo é ele próprio o "com mais forte razão de Deus". Jesus no Evangelho é inicialmente aquele que fala e diz a boa nova. Agora ele é anunciado como aquele que, através da loucura da Cruz, quebra a norma de equivalência do pecado e da morte. Há um combate de gigantes: lei e graça; morte e vida. O primeiro homem, de um lado: "se pela culpa de um só..." De outra parte, o homem verdadeiro "com mais forte razão a graça de Deus e o dom conferido pela graça de um só homem, Jesus Cristo, se espalharam em profusão pela multidão". A Igreja, pela boca de São Paulo, dá um nome, o nome de Jesus Cristo à lei da superabundância. Há signos concretos desta economia nova. O perdão pode ser um deles (MIGLIORI, 2007, p. 46).

A justificação de Paulo é um elemento central nas articulações do perdão, pois nosso filósofo acrescenta à análise do perdão a lógica do excesso ou da superabundância paulina. Existe uma reciprocidade entre o dar e o receber que soluciona o problema da dissimetria horizontal do dom sem espírito de retribuição. Dessa 
maneira, o reconhecimento da dimensão de reciprocidade da relação entre pedido e oferecimento do perdão constitui uma etapa primordial na reconstrução desta relação. Nosso filósofo sustenta a economia do dom em uma perspectiva de doação originária e por meio de um enraizamento teológico: a religião intenta situar toda experiência na perspectiva da economia do dom.

Dizer perspectiva, não é dizer fundamento, mas sentido, isto é, ao mesmo tempo significação e direção; dizer dom é ter em vista uma doação originária, que tem como beneficiária toda criatura, e não apenas a humanidade e sua moralidade, a qual está bem fundada sobre si mesma. Dizer economia é dizer que o dom se exprime numa rede simbólica, muito mais vasta que aquela que gravita em torno da confissão e da remissão dos pecados. O primeiro predicado de bondade, que resulta nessa economia do dom, está ligado ao ser criado enquanto tal; ele está, pois, antes de toda determinação propriamente moral. Dele se lê a primeira expressão bíblica próxima do final da narrativa da Criação: Deus viu tudo o que havia feito. Eis que era bom. Este é o sentido supramoral da bondade na economia do dom. Reconhecer esta bondade da Criação é responder-lhe com uma humildade reverencial a respeito do Criador e com uma compaixão sem limites por todas as criaturas (RICOEUR, 1992, p. 177).

O lugar privilegiado do perdão estaria em um ponto de convergência entre a lembrança e o luto. Por isso, podemos imaginar uma espécie de cura pelo perdão, por meio de uma vulnerabilidade intrínseca ao humano, iniciando na região da memória e prosseguindo pelo esquecimento. O perdão e o esquecimento possuem uma relação fundamental, pois agrega à lembrança e ao luto a dimensão da generosidade. Nessa perspectiva, nos ajuda também a teóloga mexicana Bárbara Andrade:

[...] A experiência de fé, de sermos incondicionalmente amados, abre nossos olhos e nos faz ver os outros sob nova luz; aparecem-nos como incondicionalmente ama- 
dos como nós mesmos e, por isso, perdoados como nós. Por isso, já não percebemos pecadores, e sim pessoas que vivem junto a nós no "espaço da graça". Como é possível nos incomodarmos com um pecado já perdoado? Como podemos julgar alguém que já foi justificado? Pareceria que, na experiência de fé, a única atitude coerente com o "abraço trinitário" seria o perdão. Se assim fosse, se seguiria uma conseqüência importante: se no perdão aprendemos a perdoar, já não podemos reconhecer nenhum pecado, mas apenas um pecador perdoado - e isso averiguaria exatamente na medida em que aprendêssemos a perdoar. Poderíamos, pois, chegar a esta formulação fundamental: a experiência de fé tem a característica de nos deixar sem critério algum para o reconhecimento do pecado (ANDRADE, 2007, p. 29).

A lógica da superabundância em Paulo, que se opõe à lógica da equivalência da lei acrescenta elementos que compõem a economia da dádiva que interrompem o esquema dívida-pagamento.

Podemos aqui afirmar que as misérias pelas quais a vinda do Cristo tem por finalidade remediar são formas ou consequências do pecado. O dogma da queda confirma esta conclusão. Na origem da economia redentora é necessário inserir a afirmação trazida por Deus para reerguer o gênero humano, após o desastre da queda. O dogma da redenção pressupõe aquele da encarnação, do qual é prolongamento. A ideia da redenção nos convida a ver em Deus um pai sempre pronto a nos socorrer e conceder seu perdão. As parábolas como as do filho pródigo e do bom pastor são, simultaneamente, reveladoras das possibilidades de conversão e o auxílio preventivo que ele pode esperar de Deus. É possível, dessa forma, alcançar a libertação do mal e a remissão das dívidas.

Ricoeur, ao examinar qual o sentido filosófico que se pode relacionar à Paixão e à morte de Jesus, afirma a existência de uma tradição majoritária, com base no Novo Testamento, que compreen- 
deu esta morte em termos de sacrifício. Ou seja, Jesus foi punido em nosso lugar. Por outro lado, há outra tradição que vai além, pois acentua o dom gracioso que Jesus permite com sua existência: "Não há maior amor que o de dar sua vida por seus amigos" (Jo, 16,13). Ricoeur afirma assim a libertação da teologia da cruz de uma interpretação sacrificial.

[...] Nunca temos o direito de especular nem sobre o mal que nós começamos, nem sobre o mal que encontramos fora de qualquer referência à história da salvação. O pecado original é apenas um anti-tipo. Ora, tipo e anti-tipo não são apenas paralelos, mas há um movimento de um para o outro, um "quanto mais", um "e principalmente": "Onde o pecado se multiplicou, a graça superabundou" (Rm 5,20) (RICOEUR, 1969, p. 281).

O perdão, em analogia à Graça, é entendido então como imprescindível à justiça. Os sacrifícios humanos se superam, dissolvendo-se a busca da justiça perante o cumprimento das leis, subvertendo-as. Os sacrifícios perdoam as dívidas que a lei estabelece. Trata-se da flexibilidade da lei mediante a justiça, emanando do amor ao próximo, do reconhecimento do outro, anterior à lei, cujo cumprimento produz justiça.

Apenas a experiência do perdão nos capacita para ver a realidade com novos olhos. A gratuidade da graça é experimentada como "ausência da violência que esperávamos e, por isso, com o dom de algo que não esperávamos". Enquanto tradicionalmente o pecado original foi explicado como ausência da graça, temos aqui o contrário: a graça é a ausência de violência provocada pelo pecado original (ANDRADE, 2007, p. 159).

O apóstolo Paulo dá testemunho do poder da graça que é nova criação, diante da qual não é possível mais sustentar a violência da humanidade, pelo único motivo de que a graça é "superabundante" (tema que trataremos no tópico final desse capítulo). 
Então, também para Paulo, vale que o pecado possa ser conhecido somente na fé. A experiência de fé do justificado consiste em que exclusivamente o dom da graça superabundante revela a ele que desde sempre esteve sob o poder do pecado. A palavra "perdão" não aparece em Rm 5, 12-21, porém, em seu lugar estão as palavras "dom-oferta" (dórema) "gratuitamente, como oferta" (doreán) e, vez por outra, "graça” (cháris) (ANDRADE, 2007, p. 116).

Jesus inaugurou uma "fase do perdão" na humanidade. Embora esse ato tenha sido feito em uma esfera religiosa, sem dúvida há um ultrapassamento para o campo cultural. O Perdão interfere claramente na questão da Justiça no Ocidente, por exemplo. Jesus ensina aos escribas e fariseus que não é verdade que apenas Deus tem o poder de perdoar. Ele mesmo opera um milagre na tentativa de provar que "O Filho do Homem tem sobre a Terra o poder de perdoar pecados" (Lc 5, 21-42). A formulação de Jesus é radical, uma vez que o Evangelho não afirma que o homem deve perdoar porque Deus perdoa, mas que cada um deve perdoar a partir de sua consciência. Deus perdoa "nossas dívidas, assim como perdoamos nossos devedores", diz a oração que Jesus nos ensinou (Lc 11, 1-13).

Assim, partindo da experiência de fé, já não existe acesso direto à compreensão do pecado, mas apenas indireto. O resultado é que o tratamento tradicional do pecado original seguido pela apresentação da graça foi invertido, ainda que agora tenhamos a vantagem de ter assumido o consenso teológico atual de que o privilégio corresponde à graça. Na perspectiva da experiência do perdão e da esperança fundada na cruz e na ressurreição, bem como com a liberdade como o ser libertado e curado no encontro com Deus, podemos concluir que: no encontro com Deus experimentamos, pela fé, um perdão que pela primeira vez nos revela 
nossos pecados. Ele nos liberta e capacita para o encontro com o outro. Ou seja, a graça de Deus está sempre presente, contígua a qualquer momento histórico, assim como subversiva a ele. Não é a autotranscendência humana universal que se torna explícita durante os eventos e as narrações sobre a salvação, mas a manifestação visível da doação gratuita e universalmente presente em Deus, permitindo que nos tornemos receptáculos vivos em vez de reiterarmos nossos modos de apropriação do outro que nos forma, o qual é revelado como puramente gratuito. No entanto, uma das intuições reveladas pela doutrina do pecado original nos mostra que o dano da queda foi incidido exatamente em nossa capacidade de receber gratuitamente.

É importante ressaltar que essa preocupação com a gratuidade reaparece no fragmento póstumo de Ricoeur (Vivant jusqu'à la mort). Por um lado, sua investigação é sustentada por uma atitude agnóstica em vista da autonomia do discurso filosófico. De outra parte, ela é sustentada pela motivação de fornecer fundamento à fé na condição de recurso não-filosófico, problemática que acompanhou nosso filósofo em toda sua vida. Ele afirma que é um "filósofo sem absoluto" ligado por essa atitude agnóstica, anunciando que é um "cristão de expressão filosófica". Essa disposição é, segundo ele, aquela de assumir uma situação esquizoide que tem sua dinâmica, seus sofrimentos e suas pequenas alegrias.

Minha distinção ipse/idem pode ajudar? Eu sou prudente: refúgio no ipse? Renunciar mesmo à ipseidade? Aqui o "budismo" pode ajudar, na medida em que no meu tema da atestação pode se esconder uma resistência ao "desprendimento". Eu diria hoje: defensiva filosófica do ipse para uma ética da responsabilidade e da justiça. Renúncia ao ipse para uma preparação para a morte 
(RICOEUR, 2007, p. 84). ${ }^{6}$

A autonomia do discurso filosófico coloca em evidência a autossuficiência da pesquisa filosófica e da estrutura do discurso filosófico. Os sofrimentos designam a dificuldade de reconciliação: o esforço para manter sem cessar a autonomia do discurso filosófico, sem o confrontar com a fé bíblica, provoca por vezes a contradição. As pequenas alegrias significam talvez um estado de equilíbrio, de consentimento ao que é. A fé bíblica independente é preservada do ato livre do filosofar e, dessa forma, as duas esferas são colocadas em tensão.

Então, minha questão: a morte seria mais real que a vida fora da prosopopeia do "Mal absoluto"? Isso coloca, é verdade, outro problema que reencontrarei sem dúvida mais longe: minha convicção de que as figuras do mal não constituem sistema, como poderíamos pensar do bem. Auschwitz e o Goulag são distintos. Um não é mais do que o outro: incomparáveis em graus de maldade. É uma objeção a uma enumeração reunida diferentemente que pela comparação? Pela figuração, por que não a encarnação? (RICOEUR, 2007, p. 57). ${ }^{7}$

Dessa forma, podemos afirmar uma lógica do perdão que não deriva de uma retribuição. Em Soi-même comme un autre, Ricoeur retorna à regra de ouro. Essa regra indica a importância de tomar iniciativas com respeito a outrem. Dessa maneira, o Evangelho

6. Est-ce que ma distinction ipse/idem peut aider? Je suis prudente: refuge dans l'ipse? Renoncer même à l'ipséité? Ici le "bouddhisme" peut aider, dans la mesure où dans mon thème de l'attestation peut se cacher une résistance au "détachement". Je dirais aujourd'hui: defensive philosophique de l'ipse pour une étique de la responsabilité et de la justice. Renoncement à l'ipse pour une préparation à la mort.

7. Alors, ma question: la Mort serait-elle plus réelle que la vie hors de la prosopopée du "Mal absolu"? Cela pose, il est vrai, un autre problème que je rencontrerai sans doute plus loin: ma conviction que les figures du mal ne font pas système, comme on peut le penser du bien. Auschwitz et le Goulag sont distincts. L'un n'est pas plus que l'autre: incomparables en degré de mal. Est-ce une objection à une énumération rassemblée autrement que par la comparaison? Par la figuration, pourquoi pas l'incarnation? 
de Lucas porta sabedoria: "Aquilo que você quer que os homens façam por você, faça semelhantemente por eles" (Lc 6,31). Para o filósofo francês, a regra de ouro pertence a uma economia do dom. Graças a ela, é possível relacionar a ética teleológica e a moral dita deontológica.

Paul Ricoeur oferece, desde Soi-même comme un autre, pelo menos três razões para adotar a regra de ouro como princípio da moralidade. A primeira consiste no privilégio concedido pela regra de ouro ao aspecto intersubjetivio da ação humana, o que é pressuposto, em particular, pela segunda formulação do imperativo categórico. A segunda razão consiste no fato da regra de ouro pressupor na interação humana a fundamental dissimetria entre o que um faz e o que o outro sofre. A terceira razão, proposta nos termos kantianos, fundamenta-se no fato de que a regra de ouro é formal sem ser vazia, ou seja, diz respeito aos bens que não são postos arbitrariamente pelo exercício da ação de um agente racional e responsável. Nesta perspectiva, o próprio exercício da liberdade fica condicionado à disposição de certos bens fundamentais e frágeis, cuja obtenção depende do outro. A regra de ouro alude, assim, aos bens que cada um desejaria ou não que lhe fossem proporcionados (SALLES, 2013, p. 110).

Dessa maneira, a dialética entre amor e justiça não pretende eliminar o contraste existente entre a lógica da superabundância e a lógica da retribuição. Ao contrário, uma vez que sustenta que a justiça é o meio necessário ao amor, e que a generosidade deve ser incorporada aos códigos jurídicos, essa dialética busca um equilíbrio reflexivo entre as duas lógicas. Por isso, "é somente no âmbito do juízo moral em situação que o equilíbrio instável entre amor e justiça pode ser instaurado e protegido" (RICOEUR, 2007, p. 33).

É essa lógica que reorganiza em um sentido poético o horizonte da regra de ouro, pois o conteúdo desta exige o poder 
da imaginação, bem como a abertura a novas possibilidades de significados. Dessa maneira, a justaposição da regra de ouro e do mandamento do amor na narrativa bíblica exige uma saída poética, podendo esta ser desenvolvida em duas dimensões: na simbólica, como no Sermão da Montanha e também no Sermão da Planície, onde é desenvolvido o primado do dom sobre a obrigação. Por outro lado, no plano teórico há uma articulação da economia do dom com a economia da reciprocidade, permitida pelo dom que gera obrigação.

Contrário ao vazio ético dos filósofos da suspeita, Ricoeur afirma uma reinterpretação da regra de ouro no sentido do mandamento do amor. O primeiro exige a lógica da reciprocidade e o segundo a do dom.

\section{Conclusão}

A partir da experiência do acontecimento pascal, é possível descobrir a experiência da gratuidade como o sentido último do real. O cerne do acontecimento pascal na vida de Cristo dá testemunho da força de tal experiência, que se desdobra em sua força como fides: enquanto força do querigma, na condição do próprio perdão e na condição de reconhecimento. Assim, chegamos à possibilidade do perdão como princípio de relação, enquanto superação de reciprocidade violenta. Troca progressiva do ressentimento pelo perdão graças ao procedimento da memória, da narração e do esquecimento. A possibilidade da experiência da gratuidade como horizonte de vida agora está garantida a partir da experiência do perdão, é possível desligar o agente do ato. Um verdadeiro poder do não poder é manifesto de maneira sempre mais paradoxal graças àqueles que vivem o princípio da não violência na "tragicidade" 
da vida. "Tragicidade", agora, manifesta como gratuidade do real, como dom e excesso ${ }^{8}$.

O discurso filosófico da liberdade, então aproximado ao discurso querigmático da esperança, além de partir da distinção kantiana entre razão e entendimento, busca uma validade de pesquisa filosófica possível na reflexão sobre a religião nos limites da simples razão. Em O Voluntário e o Involuntário, a produção de uma inteligibilidade do sentido voluntário-involuntário foi feita sob a abstração da falta e da transcendência. Trata-se de uma abstração relativa à espontaneidade do corpo próprio e relativa à paixão - enquanto vertigem que tem sua fonte na alma mesma - de ser o que se é: na falta e na culpa. Além disso, no que se refere ao problema da culpabilidade, o autor não o vê como claramente definido, ao contrário, como composto por um conjunto de aporias. Faz-se necessário decifrar os sinais de cada paixão pela vivência e pela cultura, tornando difícil uma fenomenologia das paixões, limitada pelo caráter mítico da noção de culpabilidade. O mito mostra-se irredutível a uma compreensão filosófica puramente racional, o que colocaria a falta ou a culpa alinhada ao sofrimento e à morte.

A inquietude do perdão é o que permanece na liberdade apesar do mal, o ser oposto ao não-ser. Ele aparece desde que um único homem é ameaçado de não ser mais livre. O ser permanece e se intensificando se opõe ao não-ser que toma a dupla figura da ausência do perdão e da perda da liberdade, de traição das

8. Dessa forma, a teologia fundamental não pode ser compreendida senão como análise crítica da memória feliz em seu cumprimento teologal. Ou seja, o olhar teológico não consiste apenas na constatação do acontecer fenomenológico, mas antes na realização de seu cumprimento, no rompimento da mímesis e no pacífico anúncio messiânico do advento de Deus como perdão. Essa verdade libertadora instaura uma distância profética em face da loucura sacrifical e torna possível o reconhecimento daquela outra potência ativa, da força da reconciliação e do perdão. 
promessas e da destruição do si, do outro, da natureza, da cultura, etc. Diante da destruição, o perdão não cessa de construir a capacidade de ser si, diante da traição, ele se intensifica como promessa. A promessa e a construção são tão fortes que a traição e a destruição, o ser é tão forte quanto o não-ser. Isso pode ser afirmado para todos, explicação do ser para aqueles que o vivem, confirmação para aqueles que esperam, traço em relevo para os surdos e para os cegos.

Por isso, podemos afirmar que a inquietude do perdão está fundamentada na paz, na abertura à felicidade uma vez que o ser é vencedor. O que advém daí é a liberdade e o perdão que são conjuntamente vividos, em um novo começo no qual o homem está em relação imediata com a origem com outro que se tornou amigo, em uma continuação de amizade e no fechamento da inimizade. A amizade é a humildade e a generosidade divididas. Ela funda a reciprocidade dos gestos e das palavras, na coragem e na gratidão, a expressão mútua do reconhecimento do outro livre.

A amizade no perdão está no fundamento de um mundo mais pacificado e mais feliz, porque ela o porta e o desenvolve, sendo recurso contra o mal. É o que anuncia as Escrituras como condição de narrativas e que tentamos em explicitar anteriormente: a inquietude do perdão. Ela se desenvolve na mutualidade expressiva de um e outro homem desde a origem, do mais íntimo do corpo e da alma do homem até o mais profundo do que o homem pode conservar do mundo, do si e da origem. Ela é conhecida como portando em seu paroxismo suas capacidades de emoção, de atenção, de memória e de imaginação, de ser e de prometer, de decidir, de conhecer e de reconhecer. Ela é expressividade, alternância no ritmo modulado de silêncio e de expressão, e capacidade de voltar 
à essa alternância uma vez que ela foi perdida.

A expressividade do perdão é a verdade da liberdade como conhecimento de sua origem transcendente no dom do perdão. Ela é conhecimento na ação livre, reconhecimento da origem como origem de toda liberdade e dos bens e leis que tornam possível no começo como em cada momento. Ela é gratidão ao redor da origem como de todo homem testemunha da origem por sua vida. Podemos presenciá-la em todas suas dimensões: do psicológico ao político, do metafísico ao antropológico e ao ontológico.

\section{Referências}

ANDRADE, Bárbara. Pecado original... ou graça do perdão? São Paulo: Paulus, 2007.

DERRIDA, Jacques. De la Grammatologie. Paris: Les Éditions de Minuit, 1967.

MENDOZA, Carlos-Alvarez. O Deus Escondido da Pós-Modernidade. São Paulo: É Realizações, 2011.

MIGLIORI, Maria Luci Buff. Horizontes do Perdão. Reflexões a partir de Paul Ricoeur e Jacques Derrida. São Paulo: PUC-SP, 2007.

NANCY, Jean-Luc. Déconstruction du Christianisme 1. Paris: Galilée, 2005.

KEARNEY, Richard. Navigations. Syracure University Press, 2006.

RICOEUR, Paul. Le conflit des interprétations: essais d'herméneutique I. Paris: Editions du Seuil, 1969.

RICOEUR, Paul. Soi-même comme un autre. Paris: Seuil, 1990.

RICOEUR, Paul. O Si-Mesmo como um Outro. Campinas: Papirus, 1991.

RICOEUR, Paul. La Vie chrétienne, Journal de l'Église presbytérienne au Canada, n. 41, 4-6, 1992.

RICOEUR, Paul. A Hermenêutica Bíblica. São Paulo: Loyola, 2006.

RICOEUR, Paul. Lectures 3: Aux fronteires de la philosophie. Paris: Seuil, 1994.

RICOEUR, Paul. La critique et la conviction. Paris: Calmann-Lévy, 1995.

RICOEUR, Paul. La mémoire, l'histoire, l'oubli. Paris: Seuil, 2000. 
RICOEUR, Paul. Vivant jusqu à la mort. Paris: Seuil, 2007.

SALLES, Sérgio. A regra de ouro entre o Amor e a Justiça: uma leitura sobre Paul Ricoeur. Belo Horizonte: Sapere Audere, 2013.

VILLAVERDE, Agís. A força da razão compartida. Lisboa: Instituto Piaget, 2004. 